\title{
PERFORMANCE OF CONCRETE MADE WITH CRUSHED CLAY BRICKS AS COARSE AGGREGATE
}

\author{
GHANim Hussein QOJA and YoukHanna ZaYia DinkHa \\ Dept. of Civil Engineering, University of Duhok, Kurdistan Region-Iraq
}

\begin{abstract}
Because of economic considerations and thermal insulation requirements, it seems necessary therefor to produce lightweight concrete obtained by crushing an enormous tons of building demolition wastes have been produced. In this study, it is gintended to investigate smashed and the possibility of using crushed clay bricks to replace the coarse aggregate (gravel) in concrete mies. Four nominal normal concrete mixes and four more mixes of crushed clay brick aggregate were prepared and tested. The crushed clay brick aggregates were produced by crushing the brick units (locally available and manufactured in Iran) manually and collected into described size $(20 \mathrm{~mm})$. From the analysis of the results, it was found that the unit weight of the crushed brick concrete ranged from $(1685-1760) \mathrm{kg} / \mathrm{m}^{3}$ and its compressive strength was about $61 \%$ of that of the natural aggregate concrete while the flexural strength was $70 \%$ of natural aggregate concrete. Also, the relation between compressive and flexural strength for the lightweight concrete produced is similar to that of normal concrete. Moreover, the results indicated the suitability of the crushed clay brick aggregate concrete to be used in buildings.
\end{abstract}

KEYWORDS: Recycled aggregate, Lightweight concrete, Crushed clay brick, Demolition waste.

\section{INTRODUCTION}

$\mathbf{T}$ he self-weight of normal cement concrete varies from 2200 to $2600 \mathrm{~kg} / \mathrm{m}^{3}$. This is one of the main disadvantages of conventional cement concrete as this heavy weight of concrete makes it uneconomical structural material. To increase the efficiency of cement as a structural material attempts have been made to reduce the weight of normal cement concrete.

A cement concrete having self-weight ranging from 300 to $1850 \mathrm{~kg} / \mathrm{m}^{3}$ is called lightweight concrete (Neville \& Brooks, 2010). In recent years lightweight concrete has become more popular due to manifold advantages it offers over the conventional concrete. A better understanding and development of modern technologies have also helped in the promotion and use of light weight concrete.

Concrete can be effectively produced using reprocessed materials. The use of recycled aggregate concrete has gradually increased during the last decades and its recent field of uses including lightweight concrete, lightweight aggregate, asphalt concrete and concrete used in road construction (swamy, 1983)

The use of crushed waste as aggregate in concrete has begun in Europe and Japan since the Second World War. Many buildings are constructed from crushed waste because of the need for low-cost and rapidly constructed buildings.

Crushed bricks are widely used in parts of India and Bangladesh as a substitute source of coarse aggregate and the performance of this concrete is found to be quite satisfactory (Schulz, 1988).

Brick aggregates are effortlessly presented in Bangladesh and with low cost compared to other sources of aggregates. In addition, strength of 20 MPa can be reached easily using this type of aggregate and according to the usual practice of making concrete (Rashid, Hossain, \& Islam, 2008). And the use of brick aggregate concrete effectively reduced the dead load on columns in addition to foundations. Therefore, the process of replacing the aggregates effectively reduced the cost in making concrete.

The research done by (Akhtoruzzaman \& Hasnal, 1983) mainly focused on determining the mechanical properties of brick aggregate concrete. They used burned brick in concrete as an alternative to coarse aggregate. The study showed that high strength concrete can't be achieved through using crushed brick when used as coarse aggregate.

(Khaloo, 1994) Stated that when using crushed clinker bricks in concrete as coarse aggregate, a 
reduction in concrete strength of $7 \%$ have marinated when compared with concrete manufactured with natural aggregate. Furthermore to this reduction in strength, there is a reduction in the unit-weight of crushed brick concrete of $9.5 \%$.

In a study carried out by (Husain, Al-Hamad, $\&$ Mustafa, 1995), they used treated or untreated crushed brick as an alternative to coarse aggregate. Cement syrups of different consistencies have be used to treat the aggregates. They found a reduction in compressive strength up to $75-85 \%$ when compared to normal concrete at 28 days, and a lower modulus of elasticity, even though the results of splitting tensile strength using crushed brick were more than the normal concrete.

Also, (Bolouri, Mahmood, \& Navid, 2006) used crushed brick in their study, they found that the compressive strength of concrete prepared with crushed bricks is comparatively low in comparison with ordinary concrete. Nevertheless, concrete bricks made with crushed bricks have higher strength than ordinary bricks, they could be used as new constructions.

(Abdur, Md. Abdul Salam, Sakanta, \& Md. Kowsur, June,2012) Indicated that the weight of brick aggregate concrete reduced about $14.5 \%$ compared to that of normal aggregate concrete. Also, they showed a decrease of $33 \%$ in compressive strength of concrete when using brick aggregate instead of stone aggregate moreover a $28 \%$ decrease in elastic modulus of concrete.

Widespread work on recycled aggregate concrete has proven that using of numerous types of recycled aggregate in concrete yields to a concrete with light weight and less expenses (Hughes D.A.B.,, Basheer, Elliot, \& Hackett) (Ibrahim, Shahram, Ahmed, \& Mohammed, May, 1996) (Alduaij, Alshaleh, Haque, \& Ellaithy) (Crwaford \& Cullum-Kenyon, May, 2001) (Fouad, khalaf, \& Alan, 2005).

In present study, an endeavor has been made to study the possibility of using crushed clay bricks of locally existing construction waste for production of recycled brick aggregate concrete.

\section{Cement:}

\section{MATERIALS}

Ordinary Portland cement manufactured in Sulaymaniyah-Iraq was used in the present work with properties given in Table (1).

Table (1): physical and chemical properties of the used cement

\begin{tabular}{|c|c|c|c|c|}
\hline \multicolumn{2}{|c|}{ Chemical Tests } & \multicolumn{3}{|c|}{ Physical Tests } \\
\hline Chemical Requirements & Test Results & Physical R & irements & Test Results \\
\hline Loss on ignition & $1.52 \%$ & \multirow{2}{*}{$\begin{array}{l}\text { Setting } \\
\text { Time }\end{array}$} & Initial & 137.7 minutes \\
\hline Insoluble Residue & $0.76 \%$ & & Final & 3.30 hours \\
\hline LSF & 0.86 & \multicolumn{2}{|c|}{ Soundness (Le-Chatelier) } & $1 \mathrm{~mm}$ \\
\hline C3S & $41.14 \%$ & \multicolumn{2}{|c|}{ Fineness } & $276 \mathrm{~m}^{2} / \mathrm{kg}$ \\
\hline $\mathrm{C} 2 \mathrm{~S}$ & $34.94 \%$ & \multirow{3}{*}{$\begin{array}{l}\text { Compressive } \\
\text { Strength }\end{array}$} & 3 days & $31 \mathrm{Mpa}$ \\
\hline $\mathrm{C} 3 \mathrm{~A}$ & $7.367 \%$ & & 7 days & $36 \mathrm{Mpa}$ \\
\hline C4AF & $9.819 \%$ & & - & - \\
\hline
\end{tabular}

\section{Fine Aggregate (Sand):}

The fine aggregate used was river locally available in Duhok region, it's grading satisfied the ASTM specifications (C 33-03) as shown in Table (2).

Table (2): Sieve Analysis of fine aggregate

\begin{tabular}{ccc}
\hline Sieve size (sieve No.) & \% passing & ASTM Specifications \\
\hline 4 & 100 & $95-100$ \\
\hline 8 & 92 & $80-100$ \\
\hline 16 & 75 & $50-85$ \\
\hline 30 & 49 & $24-60$ \\
\hline 50 & 17 & $10-30$ \\
\hline 100 & 5 & $2-10$ \\
\hline
\end{tabular}




\section{Coarse Aggregate:}

Natural coarse aggregate was used in reference mixes of $20 \mathrm{~mm}$ maximum size, $60 \%$ retained on sieve $(20 \mathrm{~mm})$ and $40 \%$ passing sieve $(10 \mathrm{~mm})$ and retaining on sieve $(4.75 \mathrm{~mm})$.

\section{Crushed Clay Brick Aggregate:}

Crushed clay brick aggregates were prepared by crushing the clay bricks manually as shown in
Figure (1). Crushed products were screened into two size fractions, (20 to $10 \mathrm{~mm}$ ) and (10 to 4.75 $\mathrm{mm})$. In order to produce the crushed clay brick coarse aggregate, the two size fractions were recombined by the same ratios as natural coarse aggregate to give a similar grading. The properties of crushed brick aggregate are presented in Table (3).

Table (3): Crushed clay brick properties

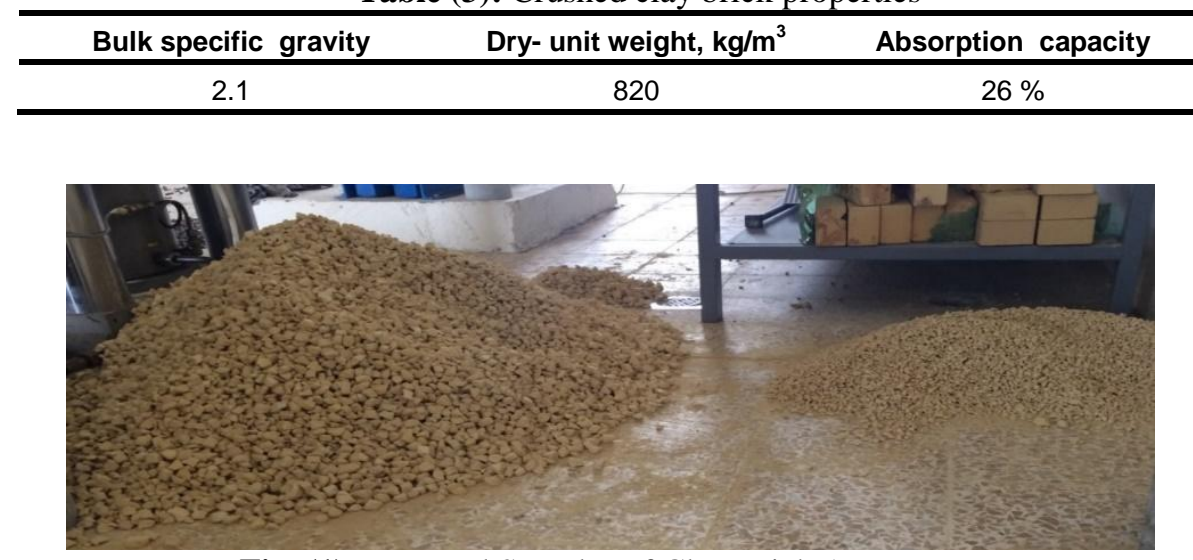

Fig. (1): Prepared Samples of Clay Brick Aggregate.

\section{Mixing Water:}

Ordinary drinking (Tap) water was used in3.1 Mix Proportions: preparing all concrete mixes.

\section{EXPERIMENTAL WORK}

Four different nominal mixes were tried throughout the present work, their main characteristics are listed in Table (4).

Table (4): Characteristics of nominal mixes

\begin{tabular}{ccc}
\hline Mix No. & Mix proportion & Cement content $\mathbf{~ g g} / \mathbf{m}^{3}$ \\
\hline 1 & $1: 1.5: 3$ & 400 \\
& $(1: 4.5)$ & \\
\hline 2 & $1: 2: 4$ & 320 \\
& $(1: 6)$ & \\
\hline 3 & $1: 2.5: 5$ & 270 \\
& $(1: 7.5)$ & 230 \\
\hline 4 & $1: 3: 6$ & \\
\hline
\end{tabular}

\subsection{Preparation and Testing of Specimens:}

The coarse aggregate was prepared as saturated surface dry condition before mixing with other ingredients. Whereas the fine aggregate was used as air-dry condition.

The values of slump of fresh concretes for different mixes ranged from $(50 \mathrm{~mm}$ to $100 \mathrm{~mm})$. The mixes tried with natural coarse aggregate considered as reference mixes and are indicated as
A1, A2, A3 and A4, while the mixes with crushed brick are indicated as B1, B2, B3, and B4.

The specimens used for compressive strength test are cubes of size $(150 \times 150 \times 150) \mathrm{mm}$, while the specimens used for flexural strength test are prisms of size $(400 \times 100 \times 100) \mathrm{mm}$.

Mixing concrete test specimens were carried out in accordance with British Standards. For each mix, six cubes were casted and tested at ages 7 
and 28 days. Also three beams were casted and tested at the age 28 days for each type of concrete.

\section{DISCUSION OF RESULTS}

Test results for natural aggregate concrete (NAC) and brick aggregate concrete (BAC) are shown in Tables (5, 6 and 7).

Table (5): Unit weight for NAC and BAC

\begin{tabular}{ccccc}
\hline Mix No & Mix proportions & Water/cement Ratio & Unit weight, kg/m $\mathbf{m}^{\mathbf{3}}$ & $\begin{array}{c}\text { Unit weight, } \\
\mathbf{k g} / \mathbf{m}^{\mathbf{3}} \mathbf{( B A C )}\end{array}$ \\
\hline 1 & $1: 1.5: 3$ & 0.42 & 2420 & 1760 \\
2 & $1: 2: 4$ & 0.46 & 2350 & 1728 \\
3 & $1: 2.5: 5$ & 0.52 & 2280 & 1704 \\
4 & $1: 3: 6$ & 0.62 & 2230 & 1685 \\
\hline
\end{tabular}

Table (6): Compressive and Flexural Strength for NAC

\begin{tabular}{cccc}
\hline Mix No & $\begin{array}{c}\text { Comp. Strength } \\
\text { (7 days) , (MPa) }\end{array}$ & $\begin{array}{c}\text { Comp. Strength } \\
\text { (28 days) , MPa }\end{array}$ & $\begin{array}{c}\text { Flexural Strength } \\
\text { (28 days), MPa }\end{array}$ \\
\hline A1 & 30.4 & 41.7 & 7.9 \\
A2 & 24.8 & 37.5 & 7.2 \\
A3 & 19.5 & 30.0 & 6.3 \\
A4 & 16 & 22.5 & 5.4 \\
\hline
\end{tabular}

Table (7): Compressive and Flexural Strength for BAC

\begin{tabular}{cccc}
\hline Mix No & $\begin{array}{c}\text { Comp. Strength } \\
\text { (7 days) , (MPa) }\end{array}$ & $\begin{array}{c}\text { Comp. Strength } \\
\text { (28 days), MPa }\end{array}$ & $\begin{array}{c}\text { Flexural Strength } \\
\text { (28 days), MPa }\end{array}$ \\
\hline B1 & 18.8 & 23.5 & 5.6 \\
B2 & 17.0 & 20.4 & 4.8 \\
B3 & 13.7 & 17.6 & 4.2 \\
B4 & 11.5 & 15.5 & 4.0 \\
\hline
\end{tabular}

\subsection{Effect of Brick Aggregate on concrete Properties: \\ 4.1.1 Unit Weight:}

Table (4) illustrates the unit weight of normal aggregate concrete and brick aggregate concrete for the four mixes tried throughout the present study. The unit weight of normal concrete is ranging between $2230 \mathrm{~kg} / \mathrm{m}^{3}$ and $2420 \mathrm{~kg} / \mathrm{m}^{3}$ while the unit weight of crushed brick aggregate concrete is ranging between $1685 \mathrm{~kg} / \mathrm{m}^{3}$ and 1760 $\mathrm{kg} / \mathrm{m}^{3}$. It is clear that, when the natural coarse aggregate is replaced by crushed clay brick, the unit weight decreases by about $25 \%$ and the resulting concrete may be classified as light weight concrete (Neville M. A., 1996).

Figure-2 illustrate the relationship between the aggregate/cement ratio and the unit weight for both types of the concretes. The figure shows that the unit weight of the concrete decreases with an increase in aggregate/cement ratio. Also, the unit weight of the brick aggregate concrete is about $75 \%$ of the normal aggregate concrete. 


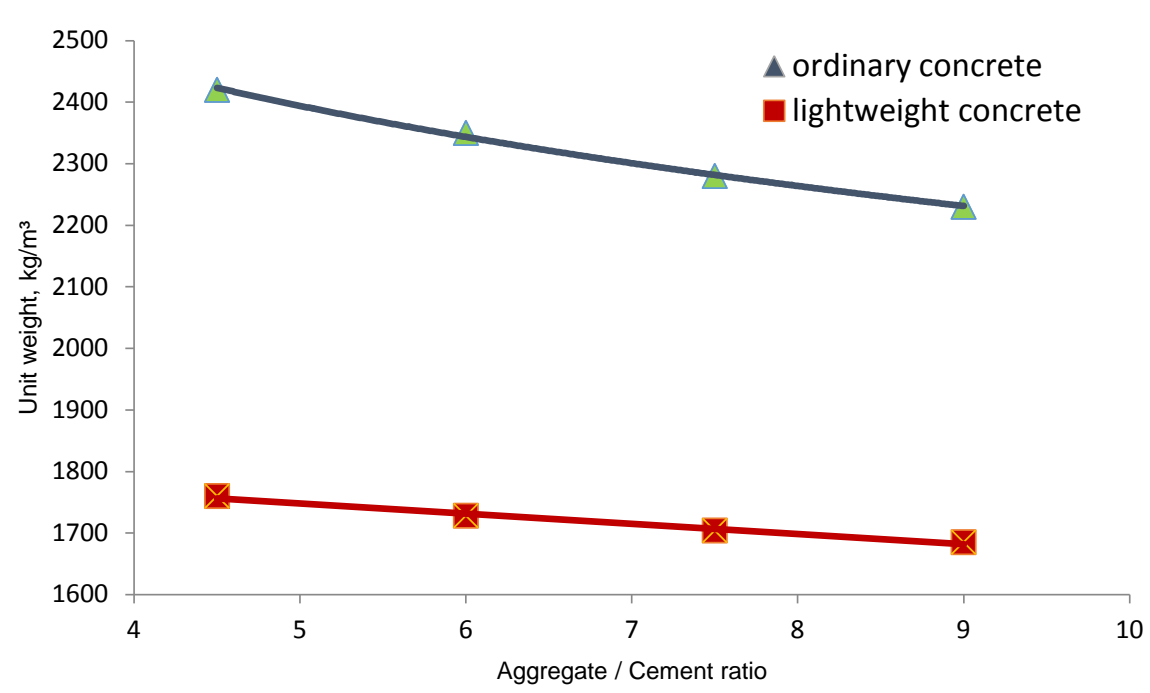

Fig. (2): Relationship between unit weight and aggregate/cement ratio

\subsubsection{Compressive Strength}

The results of compressive strength are summarized in Tables (5, and 6). It is observable that the relationship between the compressive strength and the age were similar for both natural and crushed brick aggregate concrete and that the compressive strength of concrete increases as the age of concrete increases. (The specimens of concrete were tested at ages 7 and 28 days respectively).

In general, the compressive strength of concrete produced with clay brick aggregate were always lower than the compressive strength of natural aggregate concrete. (See figures 3 and 4). We conclude from Tables (5) and (6) and from Figure (3) that the compressive strength of brick aggregate concrete is ranging between 53\% and $69 \%$ of the compressive strength of normal aggregate concrete.
Also, the compressive strength of brick aggregate concrete increases by a ratio of $52 \%$ with an increase in cement content. While the compressive strength of normal concrete increases by a ratio of approximately $85 \%$ as the cement content increases.

The effectiveness of crushed brick aggregate concrete can be predictable to be less, in terms of strength than the natural aggregate concrete due to the higher porosity of crushed aggregate of crushed brick aggregate concrete compared to normal concrete.

Moreover, the resistance to mechanical actions of crushed brick aggregates is lesser than that of natural aggregates, because of developed microcracks which are suffered during crushing of bricks.

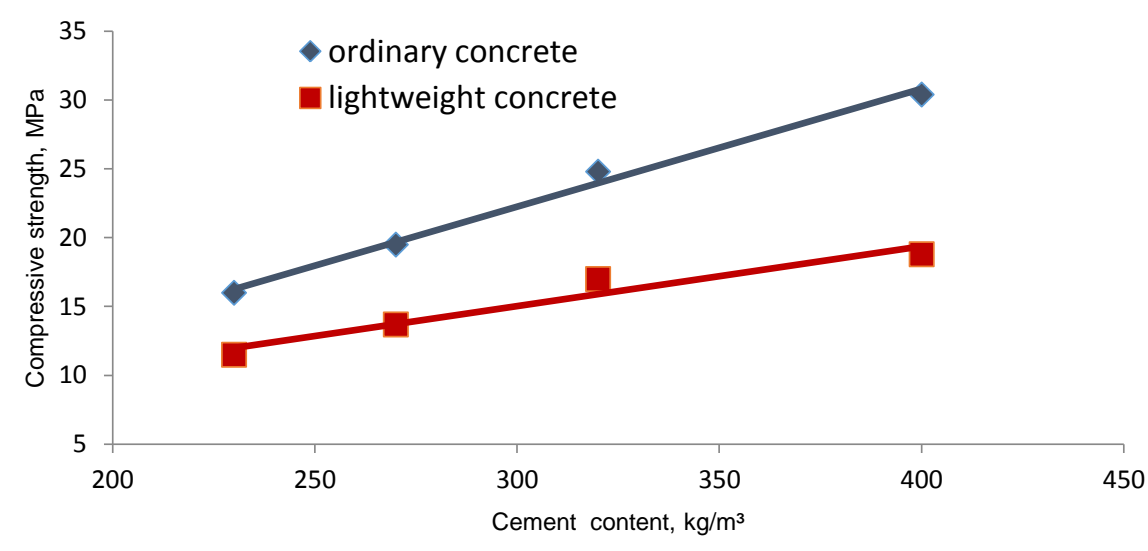

Fig. (3): Relationship between cement content and compressive Strength at 7 days 


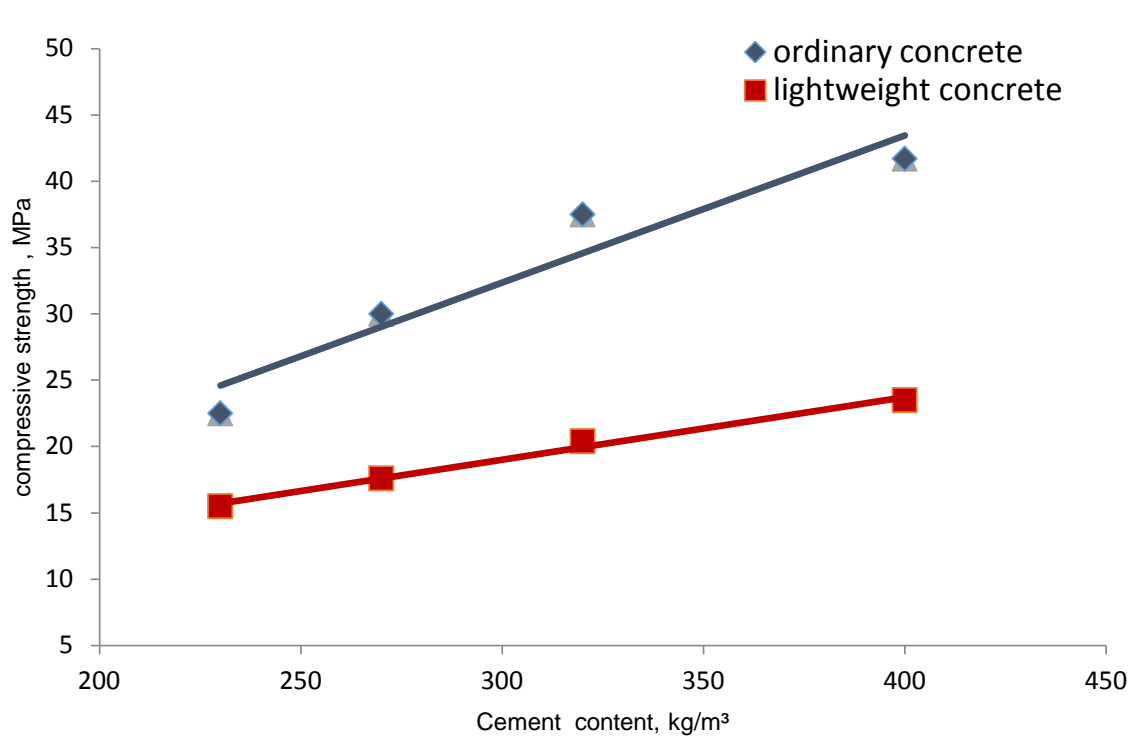

Fig. (4): Relationship between cement content and compressive Strength at28 days

\subsubsection{Flexural Strength}

The results of flexural tests for natural and crushed brick aggregate concretes are summarized in Tables (5) and (6) and Figure (5).

In general, the flexural strength of crushed clay brick aggregate concretes were always lower than natural aggregate concrete. The flexural strength of crushed brick concrete increases with an increase in cement content similar to normal concrete.

From the Tables, it seems that the flexural strength of crushed brick concrete is about $66 \%$ to $74 \%$ of that of normal concrete. This shows that the performance of crushed brick concrete is better than that its performance in compression strength and this may be due to the surface texture and the angularity of crushed clay brick aggregate.

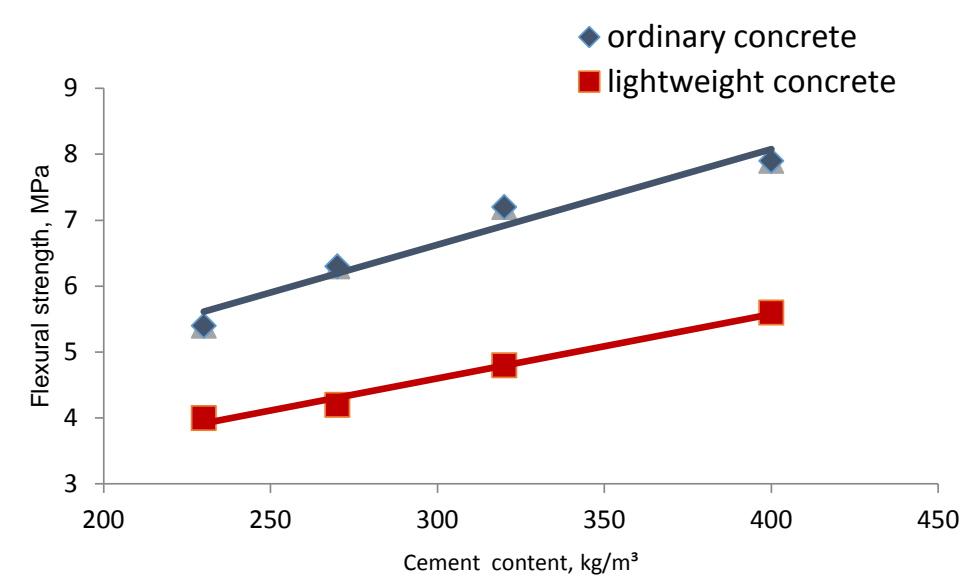

Fig. (5): Relationship between cement content and Flexural Strength at 28 days

\subsection{RELATIONSHIP BETWEEN COMPRESSIVE AND FLEXURAL STRENGTHS}

Figure (6) shows the relationship between compressive and flexural strength for both types of concretes. The flexural strength of normal concrete equals $19 \%$ to $24 \%$ of compressive strength, while the flexural strength of crushed brick concrete equals $24 \%$ to $26 \%$ of compressive strength. This means that the crushed brick aggregate concrete behaves similar to the natural aggregate concrete. But the ratios are higher in case of crushed brick aggregate for all mixes have been tried as shown in Figure (6) below. 


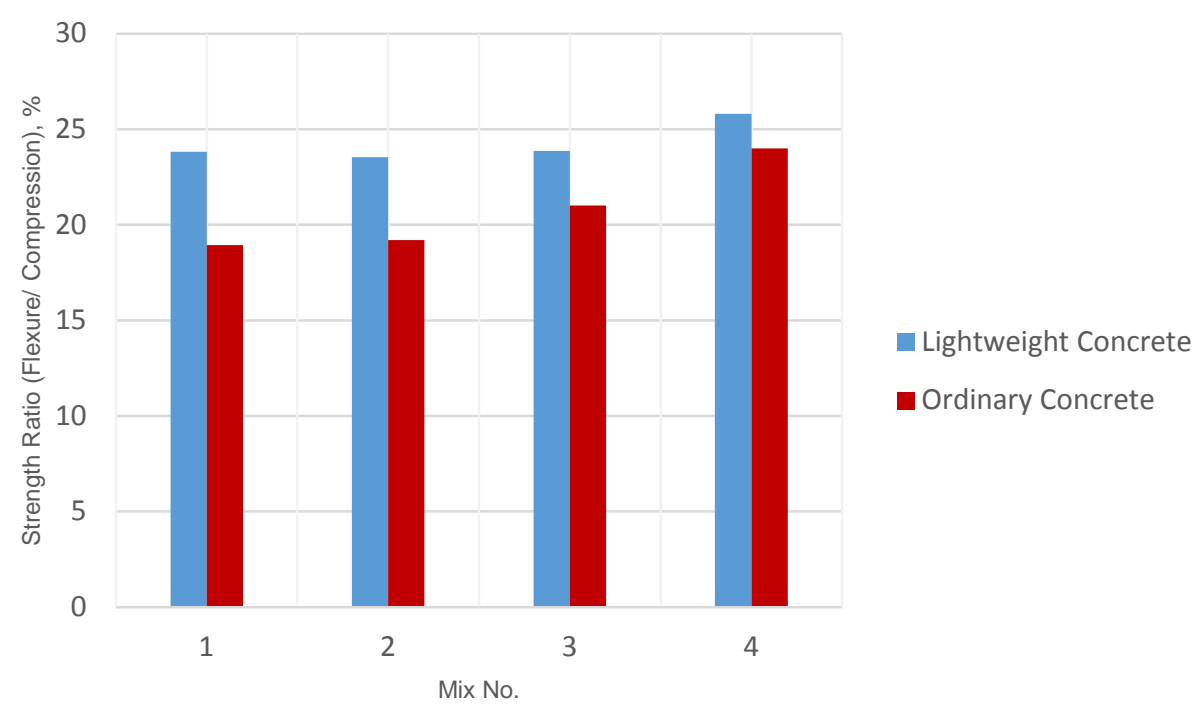

Fig. (6): Relationship between Flexural strength and Compressive Strength for NAC and BAC at 28-day

\section{CONCLUSIONS}

The following conclusions can be drawn from the present study.

1. Ability of utilization of crushed clay brick as coarse aggregate replacement of natural aggregate (gravel) to produce lightweight concrete of unit weight ranges between $(1685-1760) \mathrm{kg} / \mathrm{m}^{3}$ used in production of building units.

2. The compressive strength of crushed brick aggregate concrete is about $61 \%$ (as average) of compressive strength of natural aggregate concrete if the both have the same workability. Also, the compressive strength of crushed brick concrete increases with the increase of age and cement content.

3. The flexural strength of crushed brick aggregate concrete is about $70 \%$ of that of natural aggregate concrete. This means that the performance of concrete produced with crushed clay is better in flexure.

4. Throughout the study of the properties of crushed clay brick aggregate concrete, it is concluded the same known relations between the compressive and flexural strength, and this type of lightweight concrete produced, behaves the same as normal concrete regarding the properties that have been studied.

\section{REFERENCES}

- Abdur, R. M., Md. Abdul Salam, Sakanta, K., and Md. Kowsur , H. (June,2012). Effect of Replacing Natural Coarse Aggregate by Brick
Aggregate on the Properties of Concrete. DUET Journal, Gasipur,Vol.1.

- Akhatoruzzaman, A. A., and Hasnal, A. (1983). Properties of Concrete Using Crushed Brick as Aggregate. concrete International and Construction Vol.5, No.2. pp.58 -63

- Alduaij, J., Alshaleh, K., Haque, M., N and Ellaithy, K. (N.D.). (1999) "Lightweight Concrete in Hot Coastal Areas. Cement and Concrete Composites, Vol. 21, No. 5, pp.453-458.

- Bolouri, B. J., Mahmood, K., and Navid, A. (2006). Performance of Concrete Produced with Crushed Bricks as the Coarse and Fine Aggregate. IAEG Journal, London.

- Crwaford, H., and Cullum-Kenyon, S. (May, 2001). Market Development Study For Recycled Aggregate Products. Report to Waste Reduction Advisory Committee.

- Fouad, M., khalaf, and Alan, S. D. (2005). Properties of New and Recycled Clay Brick Aggregates for Use in Concrete. Journal of materials in civil engineering (J. mater. civ.eng.), Vol. 17, No4, pp. 456- 464.

- Hughes D.A.B.,, D., Basheer, P., Elliot, T., and Hackett, A. (n.d.). Use of Building Demolition Waste as Aggregate in concrete. European social fund, Demolition Waste.

- Husain, M., H., Al-Hamad, A. H., and Mustafa, k. K. (1995). The Use of Crushed Brick Treated with Cement Syrup as Aggregate for Concrete. Tikrit Journal of Eng. Sciences, Vol.2, No.2

- Ibrahim, S., Shahram, V., Ahmed, E., and Mohammed, F. (May, 1996). The Use of Solid Waste Materials as Fine Aggregate Substitutes in Cementitious Concrete Composites. 
Semisequicentennial Transportation Conference. Iowa State University, Ames, Iowa.

- Khaloo, A. R. (1994). Properties of Concrete Using Crushed Clinker Brick as Coarse Aggregate. ACI Materials Journal, Vol.91, No.2, 401-407.

- Neville, A. M., and Brooks, J. J. (2010). Concrete Technology, 2nd Edition. UK: Longman Group.

- Neville, M. A. (1996). Properties of Concrete. Longman, 4th Edition.

- Fouad, M., khalaf, and Alan, S. D. (2005). Properties of New and Recycled Clay Brick Aggregates for Use in Concrete. Journal of materials in civil engineering (J. mater. civ.eng.), Vol. 17, No4, pp. 456- 464.

- Hughes D.A.B.,, D., Basheer, P., Elliot, T., and Hackett, A. (n.d.). Use of Building Demolition Waste as Aggregate in concrete. European social fund, Demolition Waste.

- Husain, M., H., Al-Hamad, A. H., and Mustafa, k. K. (1995). The Use of Crushed Brick Treated with Cement Syrup as Aggregate for Concrete. Tikrit Journal of Eng. Sciences, Vol.2, No.2

- Ibrahim, S., Shahram, V., Ahmed, E., and Mohammed, F. (May, 1996). The Use of Solid Waste Materials as Fine Aggregate Substitutes in Cementitious Concrete Composites.
- Rashid, M. A., Hossain, T., \& Islam, M. A. (2008). Higher Strength Concrete Using Crushed Brick as Coarse Aggregate. Indian Concrete Journal, Vol. 82, No. 10, pp.18-23.

- Schulz, R. R. (1988). Concrete with RubbleDevelopment. in Demolition and Reuse of Concrete and Masonary, Proceedings.

- swamy, R. N. (1983). New Concrete Materials. London: Surrey University Press. Semisequicentennial Transportation Conference. Iowa State University, Ames, Iowa.

- Khaloo, A. R. (1994). Properties of Concrete Using Crushed Clinker Brick as Coarse Aggregate. ACI Materials Journal, Vol.91, No.2, 401-407.

- Neville, A. M., and Brooks, J. J. (2010). Concrete Technology, 2nd Edition. UK: Longman Group.

- Neville, M. A. (1996). Properties of Concrete. Longman, 4th Edition.

- Rashid, M. A., Hossain, T., \& Islam, M. A. (2008). Higher Strength Concrete Using Crushed Brick as Coarse Aggregate. Indian Concrete Journal, Vol. 82, No. 10, pp.18-23.

- Schulz, R. R. (1988). Concrete with RubbleDevelopment. in Demolition and Reuse of Concrete and Masonary, Proceedings.

- swamy, R. N. (1983). New Concrete Materials. London: Surrey University Press.

سهر دده ريا كونكريتا ئاماده كرى زتابوكن ئاخى ينّ شكاندى وه ك حه سو

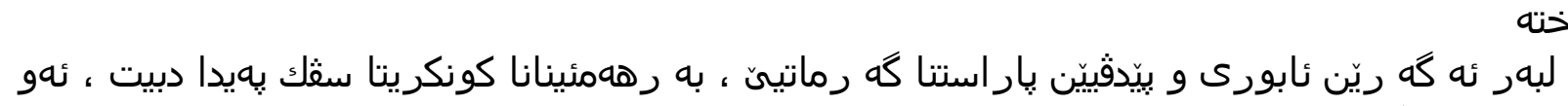

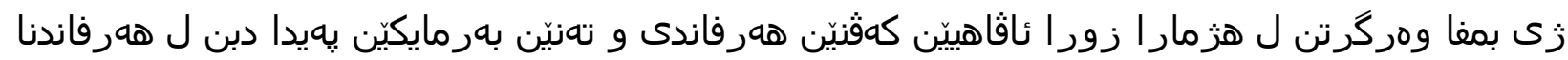

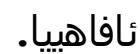
ئارمانجا ثهكوليّن ئهوه بو دياركرنا شيانا بكارئينانا تابوكى ئاخى ينّ شكاندى ل جهى حهسوى ل ناف كونكريتى دا .

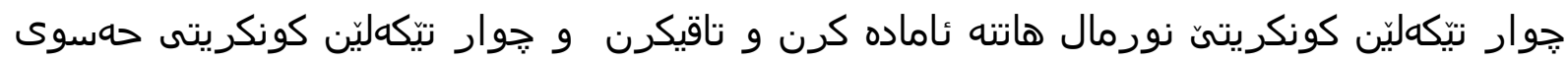

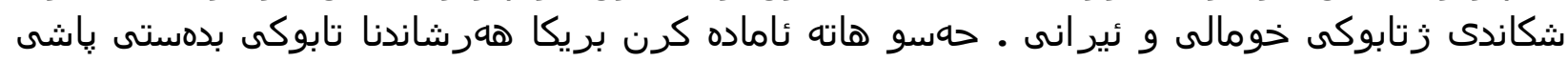

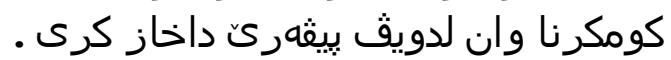

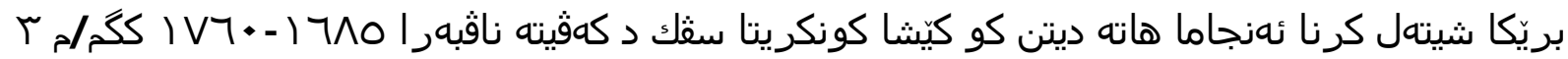

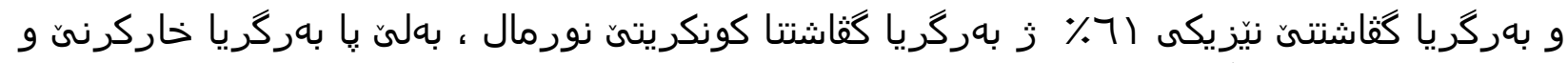

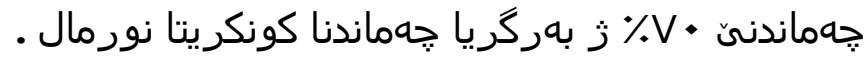

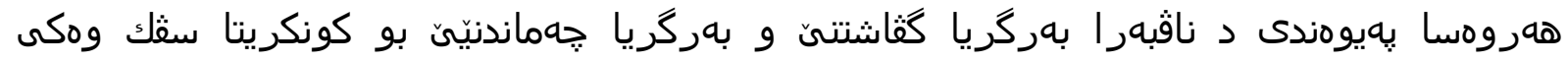

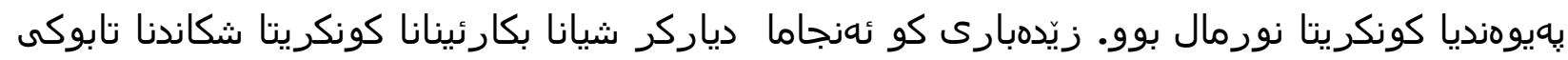
ئاخن د ناقاهيا و ريّكا دا .

اداء الخرسانة المنتجة من الطابوق الطيني المكسر كركام خشن 


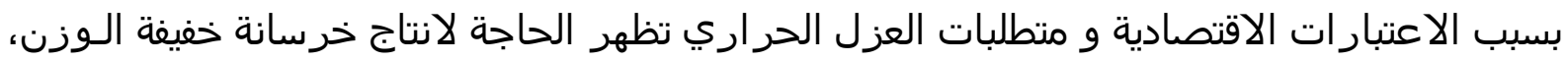

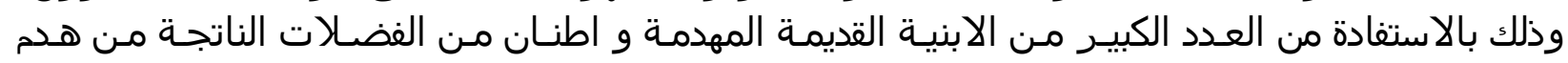

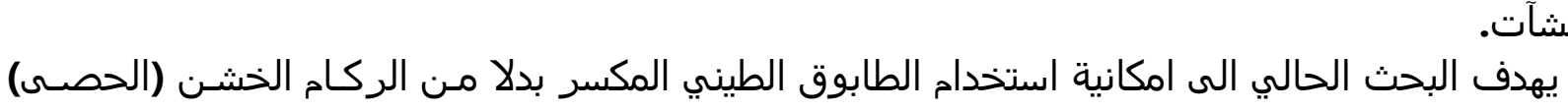
في الخلطات الخرسانية.

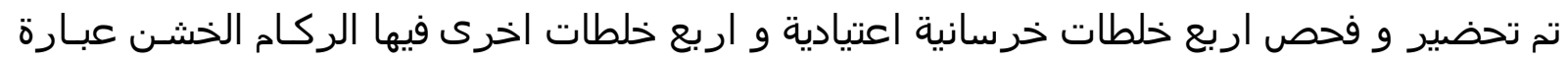

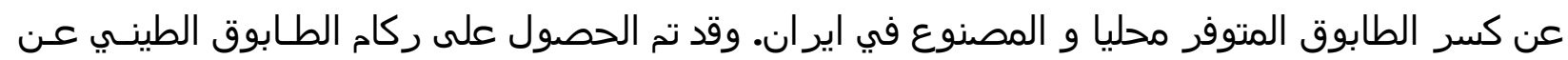

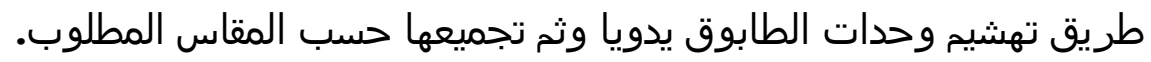

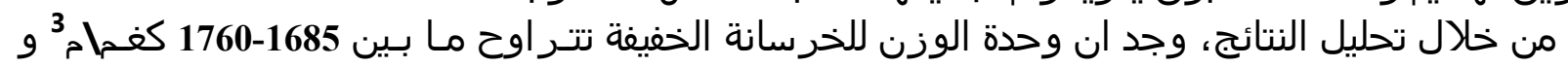

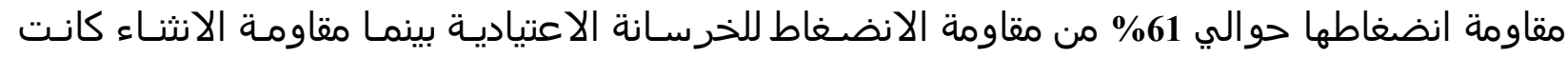

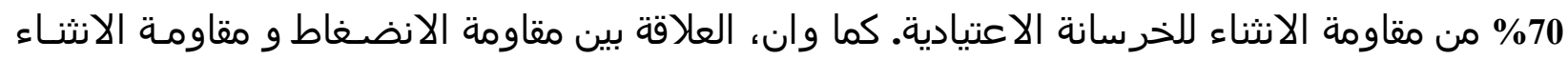

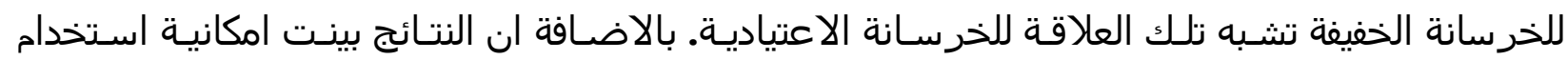

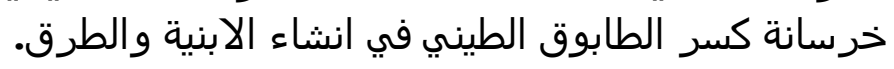

